\title{
Spiroplasma lampyridicola sp. nov., from the Firefly Beetle Photuris pennsylvanicus
}

\author{
CLAUZELL STEVENS,${ }^{1}$ AH YIN TANG,${ }^{1}$ EDWARD JENKINS,${ }^{1}+$ RICKEY L. GOINS, ${ }^{1}$ JOSEPH G. TULLY ${ }^{2}$ \\ DAVID L. ROSE, ${ }^{2}$ MEGHNAD KONAI,${ }^{3}$ DAVID L. WILLIAMSON, ${ }^{4}$ PATRICIA CARLE, ${ }^{5}$ \\ JOSEPH M. BOVÉ,,$^{5}$ KEVIN J. HACKETT, ${ }^{3}$ FRANK E. FRENCH, ${ }^{6}$ \\ JIMMY WEDINCAMP, ${ }^{6}$ ROBERTA B. HENEGAR, ${ }^{7}$ \\ AND ROBERT F. WHITCOMB ${ }^{7 *}$ \\ Department of Agricultural Sciences and Department of Microbiology, School of Veterinary Medicine, Tuskegee University, \\ Tuskegee, Alabama 36088; Mycoplasma Section, Laboratory of Molecular Microbiology, National Institute of \\ Allergy and Infectious Diseases, Frederick Cancer Research Facility, Frederick, Maryland 217022; Insect \\ Biocontrol Laboratory ${ }^{3}$ and Vegetable Laboratory, ${ }^{7}$ USDA Agricultural Research Service, BARCW, \\ Beltsville, Maryland 20705; Department of Anatomical Sciences, State University of \\ New York, Stony Brook, New York 117944; Laboratoire de Biologie Cellulaire et \\ Moléculaire, Institut Nationale de Recherche Agronomique, 33883 Villenave \\ d'Ornon Cedex, France'; and Department of Biology, Georgia \\ Southern University, Statesboro, Georgia $30460^{6}$
}

\begin{abstract}
Spiroplasma strain PUP-1 ${ }^{\mathrm{T}}$ was isolated from the gut fluids of a firefly beetle (Photuris pennsylvanicus) collected in Maryland. Cells of the strain were shown by dark-field microscopy to be helical, motile filaments. Ultrastructural examination by electron microscopy revealed filamentous cells bounded by a single cytoplasmic membrane and no evidence of a cell wall. The cells were not sensitive to $500 \mathrm{U}$ of penicillin per $\mathrm{ml}$ and grew under aerobic conditions in M1D, SP-4, and M-2 broth formulations, as well as in conventional mycoplasma medium. The doubling times at $15,20,25$, and $30^{\circ} \mathrm{C}$ were $83.1,32.0,14.9$, and $9.8 \mathrm{~h}$, respectively. Suboptimal growth occurred at $37^{\circ} \mathrm{C}$, and no growth was apparent in cultures maintained at 10 or $40^{\circ} \mathrm{C}$. The organism required cholesterol for growth and produced acid from glucose, fructose, and trehalose; arginine and urea were not hydrolyzed. The results of previous serological analyses of strain PUP-1 ${ }^{\mathrm{T}}$ indicated that the organism was not related to the then currently established Spiroplasma species or group representatives, and the organism was classified as the representative of group XIX. Additional testing of strain PUP-1 ${ }^{T}$ against recently recognized Spiroplasma species or group representatives by both metabolism inhibition and deformation tests confirmed the unique serological status of the organism. The guanine-plus-cytosine content of the DNA was $26 \pm 1 \mathrm{~mol} \%$, and the genome size was $1,375 \mathrm{kbp}$. These values clearly differentiate strain PUP-1 ${ }^{\mathrm{T}}$ from group XXI strain W115, with which it cross-reacted reciprocally at a low level in deformation and metabolism inhibition tests. We propose that strain PUP-1 (= ATCC 43206) should be recognized as the type strain of a new species, Spiroplasma lampyridicola.
\end{abstract}

Lampyrid beetles (Coleoptera: Lampyridae) (10) and mosquitoes (Diptera: Culicidae) (5) are rich sources of mollicutes. In this paper, we describe a new species whose members may occur in both of these reservoirs. Some features of spiroplasma strain PUP- ${ }^{\mathrm{T}}$, which was isolated in 1983 from the gut fluids of a firefly beetle (Photuris pennsylvanicus), were described previously (6). This strain was later examined by performing extensive serological analyses, including growth inhibition, metabolism inhibition, and deformation tests in which the organism was compared with the then currently established Spiroplasma species and group representatives (20). Although oneway serological cross-reactions were apparent between strain PUP- $1^{\mathrm{T}}$ (used as the antigen) and representatives of various groups, the pattern of responses was such that strain PUP-1 ${ }^{\mathrm{T}}$ was considered a representative of a distinct group (25). On the basis of serological data, ultrastructural features, DNA base composition, and biochemical activities, the firefly organism was designated the representative of group XIX in a revised group classification (20).

* Corresponding author. Mailing address: Vegetable Laboratory, GH3-1, Bldg. 010, Range 2, BARCW, Beltsville, MD 20705. Phone: (301) 504-8339. Fax: (301) 504-6017.

$\uparrow$ Deceased.
In this report, we describe the characteristics of this group of spiroplasmas; we include a brief summary of previously described features and results of recent extensive serological tests performed with the proposed type strain and other recently established Spiroplasma species and group or subgroup representatives. On the basis of the data obtained, we propose that strain PUP-1 ${ }^{\mathrm{T}}$ should be recognized as a member of a new species, Spiroplasma lampyridicola, as determined by the minimal standards for descriptions of new species in the class Mollicutes (12). The type strain of S. lampyridicola is PUP-1 (= ATCC 43206).

\section{MATERIALS AND METHODS}

Origins of spiroplasma strains. Strain PUP $-1^{\mathrm{T}}$ was isolated by previously described techniques (16) from the gut fluids of a firefly beetle $(P$. pennsylvanicus) collected in Maryland in 1983 (6). The organism was first cultivated in SM-1 medium and was subsequently triply cloned by plating on solid M1D medium (13). Spiroplasma strains CXN and AEF-1 were isolated from mosquitoes collected in Alabama in 1987; the medium used was M-2 medium (18), a modification of the C-3G medium of Liao and Chen (15). These isolates were triply cloned by plating on $\mathrm{M}-2$ solid medium.

The other spiroplasmas used in comparative reciprocal serological analyses of the strains described here included members of all previously established Spiroplasma species, all unnamed representatives of groups I through $\mathrm{XXV}$, and representatives of recently proposed groups XXVI through XXXIII $(20,21,27$, $31,32)$. 


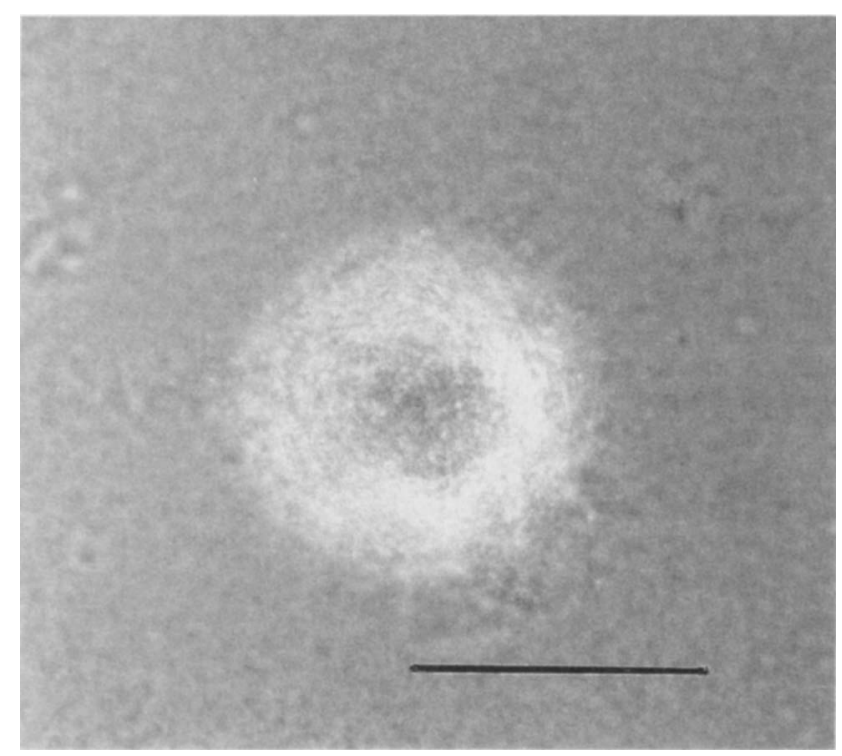

FIG. 1. Colonies of strain PUP $-1^{\mathrm{T}}$ grown on $2.25 \%$ SP-4 agar under anaerobic conditions for 4 days at $30^{\circ} \mathrm{C}$. Bar $=50 \mu \mathrm{m}$.

Culture media. M-2 medium or M1D medium (13) was used for cultivation of spiroplasma strains CXN, AEF-1, and PUP-1 ${ }^{\mathbf{T}}$ and for cultivation of most strains in serological tests. Strains of Spiroplasma mirum and Spiroplasma ixodetis were cultivated in SP-4 medium (24). Solid media were prepared by adding Noble agar (Difco Laboratories, Detroit, Mich.) to a final concentration of $3.0 \%$.

Morphological studies. Ultrastructural characteristics of strain PUP-1 ${ }^{\mathrm{T}}$ have been reported previously (20).

Temperature and filtration studies. The temperature requirements for growth were determined by a procedure described previously (1) by using a culture of strain PUP $-1^{\mathrm{T}}$ grown in M1D medium to a concentration of approximately $10^{5}$ color-changing units $(\mathrm{CCU}) / \mathrm{ml}$. Culture tubes containing $2 \mathrm{ml}$ of this culture dilution were incubated at $22,30,32,37$, and $40^{\circ} \mathrm{C}$ and were titrated at intervals by preparing a 10 -fold dilution series from each tube. Titers were expressed as the number of $\mathrm{CCU}$ per milliliter (7). The temperature requirements of strain PUP- ${ }^{\mathrm{T}}$ were also studied by the method of Konai et al. (14).

To determine filterability, an M1D broth culture of strain PUP-1 ${ }^{\mathrm{T}}$ in the late logarithmic phase was passed through a series of membrane filters with graded pore diameters $(100,220$, and $450 \mathrm{~nm})$ by using a hypodermic syringe and minimum hand pressure. Each filtrate was diluted in a 10 -fold dilution series, and the tubes were incubated at $30^{\circ} \mathrm{C}$. After 3 days, the cultures were examined for growth, and the color change and turbidity were recorded. The results were expressed as the number of $\mathrm{CCU}$ per milliliter.

Sterol requirement. The growth response to cholesterol was determined by a method modified from the standard broth culture procedure (1).

Biochemical tests. Substrate tests to determine sugar fermentation and arginine and urea hydrolysis were performed in conventional mycoplasma medium containing $1 \%$ bovine serum by procedures described previously (3).

Serological tests. Antisera to strains PUP- $1^{\mathrm{T}}, \mathrm{CXN}$, and AEF-1 and to all other spiroplasma group or subgroup representatives were prepared in rabbits by using procedures described previously (17). Reciprocal serological tests were carried out between strain PUP- $1^{\mathrm{T}}$ and all group, putative group, and subgroup representatives $(20,21,31)$. The deformation and metabolism inhibition serological test procedures used have been described previously $(29,30)$. The antisera used were derived from the reference collections maintained in the Insect Biocontrol Laboratory at Beltsville, Md., and in the Mycoplasma Section of the National Institute of Allergy and Infectious Diseases in Frederick, Md. Antigens and antisera to strains $\mathrm{CXN}$ and AEF-1 were used in reciprocal deformation tests against antigens and antisera from spiroplasma strains that were representatives of groups I through XXXIII.

\section{RESULTS AND DISCUSSION}

Morphological and cultural properties. Strain PUP- $1^{\mathrm{T}}$ grew in $\mathrm{M}-2, \mathrm{M} 1 \mathrm{D}$, and conventional mycoplasma media containing $1 \%$ serum fraction or $10 \%$ serum, as shown by the presence of turbidity and acidification of the medium within 24 to $48 \mathrm{~h}$. The strain also grew in M1D medium and SP-4 medium. The presence of penicillin $(500 \mathrm{U} / \mathrm{ml})$ had no influence on growth at $30^{\circ} \mathrm{C}$. Strain PUP- $1^{\mathrm{T}}$ grew at $22,30,32$, and $37^{\circ} \mathrm{C}$, but not at $40^{\circ} \mathrm{C}$. Optimal growth occurred at temperatures between 30 and $32^{\circ} \mathrm{C}$. Growth at $37^{\circ} \mathrm{C}$ was characterized by a brief peak titer 2 days after inoculation, followed by a rapid decline in titer. In other experiments (14), strain PUP- $1^{\mathbf{T}}$ grew at temperatures between 15 and $32^{\circ} \mathrm{C}$, and the doubling times at 15 , 20,25 , and $30^{\circ} \mathrm{C}$ were $83.1,32.0,14.9$, and $9.8 \mathrm{~h}$, respectively (14). Dark-field microscopy of cells of strain PUP-1 ${ }^{\mathrm{T}}$ in the logarithmic phase of growth revealed numerous small, helical, filamentous cells. The cells of strain PUP $-1^{\mathrm{T}}$ have been shown in previous studies to be bounded by a single cytoplasmic membrane (20). Strain PUP-1 ${ }^{\mathbf{T}}$ formed small (diameter, $<100$ $\mu \mathrm{m})$ granular colonies with dense centers on solid medium containing $3.0 \%$ Noble agar after 14 days of incubation at $30^{\circ} \mathrm{C}$ under anaerobic conditions (Fig. 1).

Filtration study. A 48 -h broth culture of strain PUP- $1^{\mathrm{T}}$ contained $10^{9} \mathrm{CCU} / \mathrm{ml}$ before filtration. The viable cell titers after filtration through membrane filters having average pore diameters of $450,300,220$, and $100 \mathrm{~nm}$ were $10^{9}, 10^{8}, 10^{7}$, and 0 $\mathrm{CCU} / \mathrm{ml}$, respectively.

Sterol requirement. No growth was apparent when strain PUP $-1^{\mathrm{T}}$ was cultivated in a serum-free base medium or in base medium containing albumin, palmitic acid, or Tween 80 (Table 1). However, spiroplasma growth was evident when the serumfree base medium contained 1 to $20 \mu \mathrm{g}$ of cholesterol per ml.

Biochemical and biological properties. Strain PUP $-1^{\mathrm{T}}$ fermented glucose, fructose, and trehalose with subsequent production of acid. Sucrose and sorbitol were not fermented. Neither arginine nor urea was hydrolyzed.

Serological tests. The results of spiroplasma deformation and metabolism inhibition tests showed that although strain PUP $-1^{\mathrm{T}}$ was reactive in some tests performed with antisera to other spiroplasmas, either the responses were one-way crossreactions or, with one exception, responses did not occur in both tests (Table 2). The single exception was the low-level reciprocal cross-reaction of strain PUP $-1^{\mathrm{T}}$ with the group XXI Oklahoma flower spiroplasma. Although the reactions were reciprocal in both deformation and metabolism inhibition tests, the levels of the reactions were low compared to the very high levels of the homologous reactions of strain PUP $-1^{\mathrm{T}}$ in the tests and represented only 0.0156 and $<0.0014$, respectively, of the homologous titers in the deformation and metabolism inhibition tests. Furthermore, genomic analyses (see below) revealed substantial differences between groups XIX and XXII. Thus, strain PUP- $1^{\mathrm{T}}$ is not related to other currently established groups, subgroups, or species of the genus Spiroplasma.

Two strains from Alabama, strain AEF-1, obtained from pools of Aedes fulvus pallens mosquitoes, and strain CXN obtained from pools of Culex nigripalpus mosquitoes, have been reported (18) to exhibit serological cross-reactions with

TABLE 1. Sterol requirement of strain PUP-1 ${ }^{\mathrm{T}}$

\begin{tabular}{llcccc}
\hline \multirow{2}{*}{$\begin{array}{c}\text { Basal medium } \\
\text { supplement(s) }\end{array}$} & $\begin{array}{c}\text { Cholesterol } \\
\text { concn } \\
(\mu \mathrm{g} / \mathrm{ml})\end{array}$ & \multicolumn{4}{c}{$\begin{array}{c}\text { Spiroplasma titer } \\
\text { (CCU/ml) on }\end{array}$} \\
\cline { 3 - 6 } & & Day 3 & Day 9 & Day 10 & Day 20 \\
\hline None & 0 & $\mathrm{~N}$ & $\mathrm{~N}$ & $\mathrm{~N}$ & $\mathrm{~N}$ \\
Bovine serum fraction (1\%) & 0 (control) & $10^{6}$ & $10^{10}$ & $10^{10}$ & $10^{10}$ \\
Albumin $(0.5 \%)+$ palmitic & 0 & $\mathrm{~N}$ & $\mathrm{~N}$ & $\mathrm{~N}$ & $\mathrm{~N}$ \\
acid $(10 \mu \mathrm{g} / \mathrm{ml})+$ & 1 & $\mathrm{~N}$ & $\mathrm{~N}$ & $\mathrm{~N}$ & $10^{6}$ \\
Tween $80(0.01 \%)$ & 5 & $\mathrm{~N}$ & $\mathrm{~N}$ & $10^{1}$ & $10^{9}$ \\
& 10 & $\mathrm{~N}$ & $\mathrm{~N}$ & $10^{1}$ & $10^{9}$ \\
& 20 & $\mathrm{~N}$ & $\mathrm{~N}$ & $10^{1}$ & $10^{9}$ \\
\hline
\end{tabular}

${ }^{a}$ Cultures were incubated at $30^{\circ} \mathrm{C} . \mathrm{N}$, no growth. 
TABLE 2. Serological reactivities of spiroplasma strain PUP-1 ${ }^{\text {Ta }}$

\begin{tabular}{|c|c|c|c|c|c|}
\hline \multicolumn{2}{|c|}{$\begin{array}{l}\text { Challenge } \\
\text { organism }\end{array}$} & \multicolumn{2}{|c|}{$\begin{array}{l}\text { Deformation } \\
\text { test }\end{array}$} & \multicolumn{2}{|c|}{$\begin{array}{c}\text { Metabolism } \\
\text { inhibition test }\end{array}$} \\
\hline Group & Strain & Antigen ${ }^{b}$ & Antiserum $^{c}$ & Antigen $^{d}$ & Antiserum ${ }^{e}$ \\
\hline I-1 & $\mathrm{R} 8 \mathrm{~A} 2^{\mathrm{T}}$ & 80 & $\mathrm{n}^{f}$ & $\mathrm{n}$ & $\mathrm{n}$ \\
\hline $\mathrm{I}-2$ & BC- $3^{\mathrm{T}}$ & 80 & $\mathrm{n}$ & $\mathrm{n}$ & $\mathrm{n}$ \\
\hline I-3 & $\mathrm{E} 275^{\mathrm{T}}$ & $\mathrm{n}$ & $\mathrm{n}$ & 162 & $\mathrm{n}$ \\
\hline $1-5$ & LB-12 & 40 & $\mathrm{n}$ & 54 & $\mathrm{n}$ \\
\hline I-6 & M55 & 40 & $\mathrm{n}$ & $\mathrm{n}$ & $\mathrm{n}$ \\
\hline $1-8$ & $\mathrm{P} 40^{\mathrm{T}}$ & 40 & $\mathrm{n}$ & $\mathrm{n}$ & 162 \\
\hline II & DW-1 & 40 & $\mathrm{n}$ & $\mathrm{n}$ & $n$ \\
\hline V & $\mathrm{SMCA}^{\mathrm{T}}$ & $\mathrm{n}$ & $\mathrm{n}$ & 54 & $\mathrm{n}$ \\
\hline VII & MQ-1 ${ }^{\mathrm{T}}$ & $\mathrm{n}$ & $\mathrm{n}$ & $\mathrm{n}$ & 54 \\
\hline VIII-2 & $\mathrm{DF}-1^{\mathrm{T}}$ & 40 & $\mathrm{n}$ & $\mathrm{n}$ & $\mathrm{n}$ \\
\hline VIII-3 & TAAS-1 & $\mathrm{n}$ & $\mathrm{n}$ & 486 & $\mathrm{n}$ \\
\hline $\mathrm{X}$ & AES- $1^{T}$ & 80 & $\mathrm{n}$ & 486 & $\mathrm{n}$ \\
\hline XI & MQ-4 ${ }^{\mathrm{T}}$ & 160 & $\mathrm{n}$ & $\mathrm{n}$ & $\mathrm{n}$ \\
\hline XIII & $\operatorname{Ar} 1343^{\mathrm{T}}$ & 160 & $\mathrm{n}$ & 162 & $\mathrm{n}$ \\
\hline XVI-1 & $\mathrm{CC}-1^{\mathrm{T}}$ & $\mathrm{n}$ & $\mathrm{n}$ & 54 & $\mathrm{n}$ \\
\hline XVI-2 & CB-1 & $\mathrm{n}$ & $\mathrm{n}$ & 39,000 & $\mathrm{n}$ \\
\hline XVIII & $\mathrm{TN}-1^{\mathrm{T}}$ & 80 & $\mathrm{n}$ & $\mathrm{n}$ & $\mathrm{n}$ \\
\hline XIX & PUP-1 ${ }^{\mathrm{T}}$ & $10,240^{g}$ & 10,240 & $>117,000^{g}$ & $>117,000$ \\
\hline XX & LD-1 $^{\mathrm{T}}$ & 40 & $\mathbf{n}$ & 54 & $\mathrm{n}$ \\
\hline XXI & W115 & 160 & 160 & 162 & 162 \\
\hline XXIII & TG-1 ${ }^{\mathrm{T}}$ & 40 & $\mathrm{n}$ & $\mathrm{n}$ & $\mathrm{n}$ \\
\hline XXIV & $\mathrm{CCH}^{\mathrm{T}}$ & 20 & $\mathrm{n}$ & 1,458 & $\mathrm{n}$ \\
\hline XXVI & PLHS-1 $^{\mathrm{T}}$ & 20 & $\mathrm{n}$ & 486 & 162 \\
\hline XXVII & TALS-2 $2^{\text {T }}$ & $\mathrm{n}$ & $\mathrm{n}$ & 1,458 & $\mathrm{n}$ \\
\hline XXVIII & PALS-1 ${ }^{\mathrm{T}}$ & $\mathrm{n}$ & $\mathrm{n}$ & 54 & $\mathrm{n}$ \\
\hline XXIX & TIUS-1 & $\mathrm{n}$ & $\mathbf{n}$ & 162 & $\mathrm{n}$ \\
\hline XXX & BIUS-1 & 40 & $\mathrm{n}$ & 1,458 & $\mathrm{n}$ \\
\hline XXXI & HYOS- $1^{\mathrm{T}}$ & $\mathrm{n}$ & $\mathrm{n}$ & 54 & $\mathrm{n}$ \\
\hline XXXII & TABS- $2^{\mathrm{T}}$ & 40 & $\mathrm{n}$ & 162 & $\mathrm{n}$ \\
\hline XXXIII & TAUS-1 ${ }^{\mathrm{T}}$ & $\mathrm{n}$ & $\mathrm{n}$ & 486 & $\mathrm{n}$ \\
\hline
\end{tabular}

${ }^{a}$ Antigens and antisera of the strains were tested in all heterologous combinations against all known and putative groups and subgroups. All cross-reactions except those shown were negative.

${ }^{b}$ Reciprocal of the endpoint in a deformation test in which the antigen was tested against a heterologous antigen.

${ }^{c}$ Reciprocal of the endpoint in a deformation test in which the antiserum was tested against a heterologous antiserum.

${ }^{d}$ Reciprocal of the endpoint in a metabolism inhibition test in which the antigen was tested against a heterologous antiserum.

${ }^{e}$ Reciprocal of the endpoint in a metabolism inhibition test in which the antiserum was tested against a heterologous antigen.

${ }^{f} \mathrm{n}$, negative.

${ }^{g}$ Homologous titer of the strain in the test system. The reaction, obtained only once, is shown for completeness.

strain PUP-1 ${ }^{\mathbf{T}}$; however, the tests were performed only with antigen (not antiserum) of the candidate strains. Although moderate cross-reactions were observed, subsequent experience has indicated that some spiroplasmas, including Spiroplasma leptinotarsae (9), Spiroplasma alleghenense (2), and some strains of tabanid spiroplasmas (28), as well as $S$. lampyridicola, may exhibit extensive nonspecific one-way crossing patterns. Recent metabolism inhibition serological tests have shown that strain AEF-1 may be most closely related to $S$. culicicola (11). Strain CXN exhibited strong crossing patterns with several groups, including $S$. culicicola, $S$. velocicrescens, and $S$. lampyridicola. On balance, taxonomic placement of strains AEF-1 and CXN must be deferred, as indicated by Shaikh et al. (18), until extensive reciprocal tests have been performed with antisera prepared to the candidate strains.

Genomic analysis. The DNA base composition ( $\mathrm{G}+\mathrm{C}$ content) of strain PUP- $1^{\mathrm{T}}$ has been reported to be $26 \pm 1 \mathrm{~mol} \%$ (20). The genome size is $1,375 \mathrm{kbp}$ (4). These values are important for distinguishing strain PUP $-1^{T}$ from group XXI strain W115 (G+C content, $24 \pm 1$ mol\%; genome size, 980 kbp), with which it exhibits minor reciprocal serological crossreactivity.

Habitat. Spiroplasmas similar to strain PUP-1 ${ }^{\mathrm{T}}$ have been isolated several times from lampyrid beetles. Serologically related strains have been isolated from Photuris spp. collected in Maryland and more recently from Photuris hebe larvae and adults from Evans County, Georgia, and from Photuris lucicrescens adults from Mercer County, New Jersey (23). Beetles in general (8) and firefly beetles in particular (10) serve as important spiroplasma reservoirs. There is no information concerning the pathogenicity of the group XIX strains for either beetles or mosquitoes.

The properties of strain PUP-1 ${ }^{\mathbf{T}}$, including the lack of a cell wall, penicillin resistance, the ability to pass through $220-\mathrm{nm}$ pore-size membrane filters, and the appearance of agar colonies, are characteristic of members of the class Mollicutes (12). The helical morphology of the strain, the optimum growth temperature of 30 to $32^{\circ} \mathrm{C}$, and the genome size of $1,380 \mathrm{kbp}$ place this organism in the order Entomoplasmatales, the family Spiroplasmataceae, and the genus Spiroplasma $(19,22,26,31)$. The results of serological and genomic analyses indicate that spiroplasma strain PUP- $1^{\mathrm{T}}$ is not significantly related to previously described groups I through $\mathrm{XXV}$ or to recently proposed representatives of groups XXVI through XXXIII (20). Therefore, strain PUP $-1^{\mathrm{T}}$ represents a new species, S. lampyridicola.

Description of Spiroplasma lampyridicola sp. nov. Spiroplasma lampyridicola (lam.py.ri.di'/co.la. M.L. n. Lampyridae, the firefly beetle family; L. v. colo, to inhabit; M.L. adj. lampyridicola, an inhabitant of members of the Lampyridae).

Cells are filamentous, helical, and about $150 \mathrm{~nm}$ in diameter and lack a cell wall. Colonies on solid medium containing $3.0 \%$ Noble agar are small and granular with dense centers but do not have a true "fried-egg" appearance.

Chemoorganotroph. Acid is produced from glucose, trehalose, and fructose. Does not hydrolyze arginine or urea.

Cholesterol or serum is required for growth.

The temperature range for growth is 15 to $37^{\circ} \mathrm{C}$, and the optimum temperature is 30 to $32^{\circ} \mathrm{C}$.

Serologically unrelated to other spiroplasma species and groups.

The type strain was isolated from the gut fluids of a firefly beetle ( $P$. pennsylvanicus). Related strains have been isolated from other Photuris species and from $A$. fulvus pallens and $C$. nigripalpus mosquitoes. The pathogenicity for insect hosts has not been determined.

The $\mathrm{G}+\mathrm{C}$ content of the DNA is $26 \pm 1 \mathrm{~mol} \%$. The genome size is $1,375 \mathrm{kbp}$.

The type strain is PUP-1 (= ATCC 43206).

\section{ACKNOWLEDGMENT}

We thank Jeffrey L. Buller, Georgia Southern University, Statesboro, for his advice concerning the specific epithet.

\section{REFERENCES}

1. Abalain-Colloc, M. L., C. Chastel, J. G. Tully, J. M. Bové, R. F. Whitcomb, B. Gilot, and D. L. Williamson. 1987. Spiroplasma sabaudiense sp. nov. from mosquitoes collected in France. Int. J. Syst. Bacteriol. 37:260-265.

2. Adams, J. R., R. F. Whitcomb, J. G. Tully, E. A. Clark, D. L. Rose, P. Carle, M. Konai, J. M. Bové, R. B. Henegar, and D. L. Williamson. 1997. Spiroplasma alleghenese sp. nov., a new species from the scorpion fly Planorpa helena (Mecoptera: Planorpidae). Int. J. Syst. Bacteriol. 47:759-762.

3. Aluotto, B. B., R. G. Wittler, C. O. Williams, and J. E. Faber. 1970. Standardized bacteriologic techniques for characterization of Mycoplasma species. Int. J. Syst. Bacteriol. 20:35-58.

4. Carle, P., F. Laigret, J. G. Tully, and J. M. Bové. 1995. Heterogeneity of genome sizes within the genus Spiroplasma. Int. J. Syst. Bacteriol. 45:178181 
5. Chastel, C., and I. Humphrey-Smith. 1991. Mosquito spiroplasmas. Adv. Dis. Vector Res. 7:149-205.

6. Clark, T. B., R. B. Henegar, L. Rosen, K. J. Hackett, R. F. Whitcomb, J. E. Lowry, C. Saillard, J. M. Bové, J. G. Tully, and D. L. Williamson. 1987. New spiroplasmas from insects and flowers: isolation, ecology, and host association. Isr. J. Med. Sci. 23:687-690.

7. Clark, T. B., R. F. Whitcomb, J. G. Tully, C. Mouches, C. Saillard, J. M. Bové, H. Wróblewski, P. Carle, D. L. Rose, R. B. Henegar, and D. L. Williamson. 1985. Spiroplasma melliferum, a new species from the honeybee (Apis mellifera). Int. J. Syst. Bacteriol. 35:296-308.

8. Hackett, K. J., and T. B. Clark. 1989. Ecology of spiroplasmas, p. 113-200. In R. F. Whitcomb and J. G. Tully (ed.), The mycoplasmas, vol. 5. Academic Press, San Diego, Calif.

9. Hackett, K. J., R. F. Whitcomb, T. B. Clark, R. B. Henegar, D. E. Lynn, A. G. Wagner, J. G. Tully, G. E. Gasparich, D. L. Rose, P. Carle, J. M. Bové, M. Konai, E. A. Clark, J. R. Adams, and D. L. Williamson. 1996. Spiroplasma leptinotarsae sp. nov., a mollicute uniquely adapted to its host, the Colorado potato beetle, Leptinotarsa decemlineata (Coleoptera: Chrysomelidae). Int. J. Syst. Bacteriol. 46:906-911.

10. Hackett, K. J., R. F. Whitcomb, J. G. Tully, J. E. Lloyd, J. J. Anderson, T. B. Clark, R. B. Henegar, D. L. Rose, E. A. Clark, and J. L. Vaughn. 1992. Lampyridae (Coleoptera): a plethora of mollicute associations. Microb. Ecol. 23:181-193.

11. Hung, S. H. Y., T. A. Chen, R. F. Whitcomb, J. G. Tully, and Y. X. Chen. 1987. Spiroplasma culicicola sp. nov. from the salt marsh mosquito Aedes sollicitans. Int. J. Syst. Bacteriol. 37:365-370.

12. International Committee on Systematic Bacteriology Subcommittee on the Taxonomy of Mollicutes. 1995. Revised minimum standards for description of new species of the class Mollicutes (division Tenericutes). Int. J. Syst. Bacteriol. 45:605-612.

13. Jones, A. L., R. F. Whitcomb, D. L. Williamson, and M. E. Coan. 1977. Comparative growth and primary isolation of spiroplasmas in media based on insect tissue culture formulations. Phytopathology 67:738-746.

14. Konai, M., E. A. Clark, M. Camp, A. L. Koch, and R. F. Whitcomb. 1996. Temperature ranges, growth optima, and growth rates of Spiroplasma (Spiroplasmataceae, class Mollicutes) species. Curr. Microbiol. 32:1-7.

15. Liao, C. H., and T. A. Chen. 1977. Culture of corn stunt spiroplasma in a simple medium. Phytopathology 67:802-807.

16. Markham, P. G., T. B. Clark, and R. F. Whitcomb. 1983. Culture techniques for spiroplasmas from arthropods. Methods Mycoplasmol. 2:217-223.

17. Senterfit, L. B. 1983. Preparation of antigens and antisera. Methods Mycoplasmol. 1:401-404.

18. Shaikh, A. A., W. E. Johnson, Jr., C. Stevens, and A. Y. Tang. 1987. The isolation of spiroplasmas from mosquitoes in Macon Country, Alabama. J. Am. Mosq. Control Assoc. 3:289-295.

19. Tully, J. G, J. M. Bové, F. Laigret, and R. F. Whitcomb, 1993. Revised taxonomy of the class Mollicutes: proposed elevation of a monophyletic cluster of arthropod-associated mollicutes to ordinal rank (Entomoplasma- tales ord. nov.), with provision for familial rank to separate species with nonhelical morphology (Entomoplasmataceae fam. nov.) from helical species (Spiroplasmataceae), and emended descriptions of the order Mycoplasmatales, family Mycoplasmataceae. Int. J. Syst. Bacteriol. 43:378-385.

20. Tully, J. G., D. L. Rose, E. Clark, P. Carle, J. M. Bové, R. B. Henegar, R. F. Whitcomb, D. E. Colflesh, and D. L. Williamson. 1987. Revised group classification of the genus Spiroplasma (class Mollicutes), with proposed new groups XII to XXIII. Int. J. Syst. Bacteriol. 37:357-364.

21. Tully, J. G., and S. Razin (ed.). 1996. Molecular and diagnostic procedures in mycoplasmology, vol. 2, p. 460-462. Academic Press, San Diego, Calif.

22. Tully, J. G., and R. F. Whitcomb. 1991. The genus Spiroplasma, p. 19601980. In A. Balows, H. G. Trüper, M. Dworkin, W. Harder, and K. H. Schleifer (ed.), The prokaryotes, 2nd ed., vol. 2. Springer-Verlag, New York, N.Y.

23. Wedincamp, J., Jr. 1994. Laboratory infection and release of Spiroplasma (Entomoplasmatales: Spiroplasmataceae) from horse flies (Tabanidae: Diptera). M.S. thesis. Georgia Southern University, Statesboro.

24. Whitcomb, R. F. 1983. Culture media for spiroplasmas. Methods Mycoplasmol. 1:147-158.

25. Whitcomb, R. F., J. M. Bové, T. A. Chen, J. G. Tully, and D. L. Williamson. 1987. Proposed criteria for an interim serogroup classification for members of the genus Spiroplasma (class Mollicutes). Int. J. Syst. Bacteriol. 37:82-84.

26. Whitcomb, R. F., and J. G. Tully. 1984. The family Spiroplasmataceae, genus Spiroplasma, p. 781-787. In N. R. Krieg and J. G. Holt (ed.), Bergey's manual of systematic bacteriology, vol. 1 . Williams and Wilkins, Baltimore, Md.

27. Whitcomb, R. F., J. G. Tully, T. B. Clark, D. L. Williamson, and J. M. Bové. 1982. Revised serological classification of spiroplasmas, new provisional groups, and recommendations for serotyping of isolates. Curr. Microbiol. 7:291-296.

28. Whitcomb, R. F, F. E. French, J. G. Tully, G. E. Gasparich, D. L. Rose, P. Carle, J. M. Bové, R. B. Henegar, M. Konai, K. J. Hackett, J. R. Adams, T. B. Clark, and D. L. Williamson. 1997. Spiroplasma chrysopicola sp. nov., Spiroplasma gladiatoris sp. nov., Spiroplasma helicoides sp. nov., and Spiroplasma tabanidicola sp. nov., from tabanid (Diptera: Tabanidae) flies. Int. J. Syst. Bacteriol. 47:713-719.

29. Williamson, D. L., R. F. Whitcomb, and J. G. Tully. 1978. The spiroplasma deformation test, a new serological method. Curr. Microbiol. 1:203-207.

30. Williamson, D. L., J. G. Tully, and R. F. Whitcomb. 1979. Serological relationships of spiroplasmas as shown by combined deformation and metabolism inhibition tests. Int. J. Syst. Bacteriol. 29:345-351.

31. Williamson, D. L., J. G. Tully, and R. F. Whitcomb. 1989. The genus Spiroplasma, p. 71-111. In R. F. Whitcomb and J. G. Tully (ed.), The mycoplasmas, vol. 5. Academic Press, San Diego, Calif.

32. Williamson, D. L., J. G. Tully, L. Rosen, D. L. Rose, R. F. Whitcomb, M.-L Abalain-Colloc, P. Carle, J. M. Bové, and J. Smyth. 1996. Spiroplasma diminutum sp. nov., from Culex annulus mosquitoes collected in Taiwan. Int. J. Syst. Bacteriol. 46:229-233. 